\title{
Law and Identity in the European Integration
}

\author{
JÁNOS MARTONYI*
}

\begin{abstract}
The successful continuation of the European integration process depends, to a large extent, on the restoring the equilibrium among the various dimensions, such as the economic, the political and the cultural dimension of the process. This rebalancing should primarily focus upon the upgrading of the relatively neglected cultural area of the European construction. The qualitative upgrading of the cultural dimension must be based upon the strengthening of the European identity, which itself is an indispensable precondition of the development of a stronger Europe. Law is not only the main instrument of the economic, political and institutional integration but also a core element of European identity based upon Roman law and on the legacy of European history. Rule of law is universal and it has to be respected on all levels, international, European and national. The traditional strict, 'kelsenian' hierarchy of legal norms has been substantially loosened but not exclusively due to the emergence of European law. The geometric order of legal norms has become heterarchic and the neat ranking of the different levels as well as the absolute primacy based upon that ranking has been questioned. This refers equally to the relationship between international law and European law and between European law and the national laws of the Member States. Both the principle of the autonomy of European law and the constitutional identity of the Member States aim at protecting the core principles of the European, respectively, the laws of the Member States. The rule of law does not presuppose a neat hierarchy of legal norms. However, it requires an orderly structure, where the precise area covered by the core principles taking precedence over the rules of international or of European law are defined in a clear and foreseeable manner. While a perfect order can never be established, legal certainty and ultimately rule of law, a core element of European identity, could be substantially strengthened by mutual empathy and understanding as well as by continuous and effective dialogue, consultation and concertation between the various levels of rule making and, in particular, of judiciaries.
\end{abstract}

Keywords: European Union, rule of law, constitutional identity, hierarchy of norms, integration

The European integration process has been the most successful exercise in the history of our continent. It has been and is confronted with numerous challenges and a series of crises prompting various reactions generally called reforms. It is no surprise that the two most frequently used words in the history of European construction are crisis and reform.

One of the main reasons for this success is the fundamental and indispensable role that law, legal norms, rules and regulations have played all through this complex political, economic and institutional development.

It all started as a political project (finalité politique), born in a given historical situation. After the failure of establishing a political union, a 'European Political Community and a European Defence Community the founding fathers came to the idea that this political finality was to be achieved by means and on the basis of a gradual economic integration'. What was, however, unique, perhaps unprecedented in the exercise, was the method, the instrument of rulemaking for the building of a legal and institutional structure and establishing a constitutional order. This construction has been established and developed by the law and has been functioning through legal norms, legislation or case law, creating legal rights and obligations for the European institutions, member states, and most importantly for their citizens and economic actors as well. Without this legal construction and without its core elements the primacy of community law and its direct effect, that is without an autonomous legal order, neither the common and later the single market, nor the common

* Former Minister of Foreign Affairs of Hungary and Professor Emeritus, University of Szeged, nmjt@juris.u-szeged.hu. 
policies could have been put in place, and the economic integration could not have reached the level, by far not yet perfect, where it stands now.

One of the main factors of success, at least of the economic dimension of the project, also gave ground for criticism addressed precisely to the preponderant role of rulemaking and the legalistic approach dominating the integration process. Critiques referred to the excesses of regulatory fervour together with the rulemaking competition between European Institutions, all this contributing to the perceived or real 'competence creep' of the same institutions.

However, law is not only an instrument, a useful device of the integration process. It is, at the same time, the core element of European identity. It is often said that this identity is symbolized by the three hills; the Acropolis, the Golgotha and the Capitoleum, standing for the antique Greco-Roman cultural heritage, the Christianity and the heritage of Roman law, which directly or indirectly shaped or influenced all European national legal systems. Law is therefore an indispensable and core element of the cultural heritage upon which Europe is based and should be based also in the future.

While European construction was a political project to be put in place via economic integration, the third basic driver of any individual or collective human venture i.e. the cultural dimension upon which a European identity could be built, has largely been neglected.

Out of the three main general drivers of history of mankind: trade, representing economy, performed with excellent notes; the flag representing political power, was less successful; and Script representing culture and based upon the heritage of the past but supposed to address the present and the future essentially failed in the case of the European integration. The result is a fundamental disequilibrium between these three dimensions. The political objective is lagging behind the economic integration, while the cultural element, a common vision and identity, is no doubt, the weakest point. In other words, the Merchant went far ahead, the Soldier only followed from a distance and the Missionary representing ideas was falling behind.

It is often said that the European Union is an economic giant and a political dwarf. This statement is undoubtedly excessive but the disequilibrium between the economic weight and the geopolitical clout is evident and well reflected in the difference between the achievements of a successful trade policy and the semi successes/failures of the common foreign and security policy. The unbalance between the trade and the flag is compounded and deepened by the even more serious disequilibrium between the material and the cultural-spiritual dimension. This is the ultimate source of most of the flaws, challenges, distortions and the consecutive crises the integration has been facing, right from the beginning all through its history.

It is remarkable that law plays a significantly different role in the various fields of the integration process. The establishment and the functioning of the common and single market would have been impossible without the primary role of rulemaking, as this has been the natural cause as well as the consequence of the well-known incremental, technical, functional, reactive approach in line with what is referred to as the Monnet method or the neo-functional approach. ${ }^{1}$ Rules and regulations had to be made in order to harmonize and unify the vast variety of existing national regulations. Law was the only possible method

1 Reho (2017). 
for the organic and technocratic building up of a new structure and the instrument that best served the purpose of economic integration. Similarly, to create a common commercial policy, legislation and case law were the paramount devices the only perceptible area of external action. In fact, the scope of the common commercial policy has been progressively extended and widened not only by the subsequent treaties but also by a list of groundbreaking decisions of the Court of Justice, of which the Singapore opinion has only been the last one. ${ }^{2}$

This was certainly not the case in the field of foreign and security policy, as it is very well demonstrated by the largely restrained scope of the legal acts and accordingly the minimal role granted to the Court by the Treaties in this area. The jurisdiction of the Court is limited to monitor compliance with the provisions on the procedures and the extent of powers of the institutions for the exercise of competences (Art. 40 of TEU) and reviewing the legality of decisions providing for restrictive measures against natural or legal persons. (Art. 24 of TEU and Art. 275 of TFEU.)

For trade, law is the main and indispensable tool, while for the flag, law, as a device or instrument, only has a strongly limited role.

Law has a double role in the European integration: It is a tool or device and a basic ingredient of identity based upon the European cultural heritage. The two roles of law are closely intertwined, and interdependant. Law, as a tool, is the indispensable functional device and as an element of identity, is the cultural-spiritual basis for the strategic objectives inseparable from the system of values and principles the legal norms are supposed to reflect. Accordingly, the functional role of law is hard to be traced in the third, weakly developed, dimension of the European construction. Here the law is not a device but the heart of the vision giving a sense of purpose for the whole exercise. The two roles of law are not only interrelated but also have to keep a proper balance. The tool function can only be successful in the long run if it does not go against the value-related nature of the rulemaking. The technics used have to be in full respect of the law as a fundamental component of European identity.

It is equally important that law, when it is used as an instrument for the achievement of economic, political and societal objectives, takes fully into account and follows the demands of the systemic logic of its own internal structure, the principles and rules of its own complex structural and conceptual order. If these rules are not fully respected, the use of law as an instrument becomes dysfunctional, and the transformative effect of legal rules and regulations will be distorted.

The power of the transformative role of law has been demonstrated not only by the construction of the main elements of the European economic integration but also by the systemic changes in the Central European countries in the 90s. The main instrument of fundamental economic, political, societal and institutional transformation of the 'constitutional revolution' was dismantling, 'deregulating' an existing system whilst building up a new one. Caution had to be taken to the given structural and conceptual rules of such a complex and sensitive system as the law as an instrument of achieving fundamental political, economic and societal objectives. This is not always easy to understand for political decision makers who sometimes tend to believe that the transformative and creative power of law is unlimited and can be used irrespective of its own internal order.

2 Opinion 1/75, ECR.1975, 01355; 1/78, ECR.1979, 02871; 1/94, ECR.1994 I-05267 and 2/15, ECLI:EU:C:2017:376 
Another risk related to the use of law as a transformative and creative device does not come from the outside, the expectations or needs of political decision makers, but from the inside, the internal mechanism of law making. The huge power of law, legislation or court decisions, is never unlimited and must be exercised with reasonable self-restraint. Juridical power must have its own delimitations and has to resist not only the excessive demands coming from the outside but also its own temptations to go beyond the borders of its role and function.

In case of European law, the scope, the limits of legislation and case law raise two basic theoretical and practical questions, both related to the place of Union law in the universal hierarchy of legal norms. The first is the relationship between international law and Union law and the second is the relationship between Union law and the national laws of the Member States, with special regard to their constitutional identities as derived from their national identities 'inherent in their fundamental structures, political and constitutional...' (Art. 4(2) of TEU).

The general place of Union law, in universal hierarchy of legal norms is not unrelated with the much disputed nature of European integration and its product, the European Union. This coincidences with the classic hierarchic structure of these norms increasingly dissolving and becoming more 'heterarchical'.

No simple and clear definition can be given to the constitutional nature and the autonomy of European law as long as there is no final answer to the question whether the EU is an international organisation or some kind of quasi-federal state. This is the reason why the relationship between international law and European law has been the preferred subject of legal scholarship and also a recurring issue in the case law of the Court of Justice. The Union has legal personality and is the subject of public international law, bound to respect it, whether it is treaty law or customary law. International agreements concluded by the Union are binding both on its institutions and on its member states (Art. 216 (2) of TFEU). The Union was created by international law and the treaties creating it are themselves part of international law. The primary Union law is incorporated in international law, the latter also being subject to an ongoing and increasing fragmentation and pluralisation. Union law is therefore not only a subject of international law but also an important actor of and contributor to its development. Its contribution is also reflected by the forming and shaping of legal institutions and norms that can serve as models for universal or multilateral rules. This is the reason why Union law is often referred to as a laboratory of global rulemaking. ${ }^{3}$

The international agreements, to which the EU is a party, become integral part of the Union's legal order. This would mean that all these agreements are not only directly applicable, but also have direct effect, that is they can be directly invoked by individuals before national and EU instances. However, the recognition of direct effect, while being the main rule, has never been unconditional or automatic. The Court's case law developed two requirements for direct effect:

1. the 'nature and the broad logic' of the agreement does not preclude direct effect.

2. the provisions invoked are on the basis of their content 'unconditional and sufficiently precise'. ${ }^{4}$

3 Ziegler (2015) 2.

4 See, Joined Cases C-659/13 and C-34/14 C... J. Clark International, ECLI: EU:C:2016:74 referred to by Rosas (2018) also in Blutman (2015) 97-99. 
The application of these requirements gradually moved in the direction of a narrower recognition of direct effect, regarding both the invoking of a given provision and the invoking the invalidity of a Union legal act because of incompatibility with the agreement. Until 2008, the main line of case law was that direct effect was presumption that could be rebutted by producing proof to the absence of one of the requirements. ${ }^{5}$ The concept of the autonomy of Union law has since become more robust, and the limits to the recognition of direct effect have been strengthened. In the absence of direct effect of an international agreement, the acts of Union law must be interpreted as far as possible consistently with it. ${ }^{6}$

All this essentially refers only to the secondary legislation of the Union and does not apply to the founding treaties and other parts of primary law. In the Kadi I. case, the Court made clear that the primacy of international agreements does not extend to primary law 'in particular to the general principles of which fundamental rights form part' and 'that international agreements cannot have the effect of prejudicing the constitutional principles of the Union Treaties, which include the principles that all (Union) acts must respect fundamental rights'. ${ }^{7}$ In Kadi II. the Court further underlined that international law can only be applied (permeates in the autonomous European legal order), if it is in line with the conditions as created by the basic principles of European law. ${ }^{8}$ While the decision in Kadi I. was essentially based upon the concept of the autonomy of the legal order of the Union, in Kadi II. the Court focused upon the normative hierarchy argument.

The conclusion that can be drawn from the relevant decisions of the Court is that international law 'ranks' between the secondary legislation and the 'constitution' of the EU. International law, with the exception of ius cogens, does not rank higher than primary EU law. In particular the basic constitutional principles, whether following the argument based upon the autonomy of EU law (Kadi I.) or the normative hierarchy argument (Kadi II.) show that international law does not prevail over EU law of constitutional nature (primary law or rules enshrining basic constitutional principles). This is because the EU is not only a subject of international law but also a highly constitutionalized international organization being part of and contributing to the shaping of international law. ${ }^{9}$

There is clearly a strong and evident correlation between the limits of the supremacy of international law above Union law and the doctrine of constitutional identity developed by a series of constitutional court decisions of the member states creating similar barriers to the primacy of EU law of the constitutional principles of the member states' legal systems. ${ }^{10}$ The autonomy of EU law and the barrier it creates to the supremacy of international law as developed by the Court and the barrier created by the doctrine of constitutional identity based upon Art. 4. (2) of TEU establishing the basic principle of the respect for the member states' national identities 'inherent in their fundamental structure, political and constitutional' originate from the same fundamental principle and are based upon the same reality, which

5 Ziegler (2015) 8.

${ }^{6}$ Ziegler (2011) 300-03.

7 Kadi and Al Barakaat International Foundation v. Council and Commission, Joined cases C-402/05 P and C-415/05 P, ECLI: EU: C: 2008: 461. see Ziegler (2015) 9-10, also Ziegler (2016) / Division 17, Chapter 12/Pg. Position 41/ date 2016 p 295, and Rosas (2018) 5.

8 Commission and others v. Kadi, Joined cases C-584/10 P, C-593/10 P and C 595/10 P, ECLI: EU: 2013: 518, see: Ziegler (2015) 11-12.

9 Ziegler (2015) 2-3.

10 'The reference' (i.e. to the Autonomy of the Community Legal Order) 'is reminiscent of what amounts to the untouchable core of the German Constitution', Ziegler (2011) 295. 
is that the hierarchy of legal rules is not neat and absolute. The vertical structure of the legal order has its limits. These limits are both rooted in the core constitutional principles inherent in the EU law as well as in the national legal systems. It is only natural that the borders of both doctrines cannot be precisely drawn and are moving primarily according to the decisions both by the Court and by the constitutional courts of the member states, following not only legal considerations but also political objectives. This is what makes the scope of application of both doctrines uncertain and hard to foresee, as both are mainly shaped by case law without a system of precedents and the doctrine itself is changing according to policy objectives. As for the principle of autonomy of EU law, the precise scope of the concept has been moulded not only by decisions in the field of human rights but also by recent case law in the area of the settlement of investment disputes. While the question of the validity of dispute settlement clauses of intra-EU bilateral investment protection treaties was unambiguously (albeit with controversial reasons) answered in the negative (Achmea). ${ }^{11}$ It is still not clear whether the bilateral investment protection treaties, concluded by EU member states with third countries, meet the test established by the CETA opinion. ${ }^{12}$ The scope of the issues considered to be covered by the concept of constitutional identity, itself being a subject of legal and political debates, is also subject to changes. It can also be wider or narrower in the jurisprudence or constitutional legislation of various Member States.

The two concepts - autonomy and constitutional identity - both contribute to the same outcome, the general loosening of the hierarchic structure of the sources of law. The uncertainties displayed by the triangular relationship of international law, EU law and national law reflect the structural changes in the formerly well-established, vertical structure of legal norms. The hierarchy is progressively transforming into a more heterarchic structure, where the elements are less ranked, become non-hierarchical, and can be ranked both in horizontal and vertical positions. The word itself is borrowed from neuroscience, the science of the human brain; biology, horizontal gene transfer as well as from information science.

At the same time, the borderlines between the various elements of the structure are becoming more permeable, which again, does not promote legal certainty and predictability. The increasing legal uncertainty is only an element of the overall rise of complexity, unpredictability and disorderliness characterizing the economic, geopolitical, societal and institutional developments in the world. The tentative geometry of the order of legal norms usually starts with ius cogens that international treaties, even EU primary law cannot derogate from (Art. 53 of VCLT) at the top. It is followed by the primary law of the EU, being itself international law prevailing over other rules of a growingly fragmented international law, which is the next level. The ranking of both treaty and customary international law is higher than that of secondary legislation of EU, although the direct effect of international law is subject to the conditions as referred to above. Regarding the direct effect of customary international rules, the Court introduced additional criteria further restricting individuals' right to rely on CIL because 'a principle of customary intentional law does not have the same degree of precision as a provision of an international agreement' ${ }^{13}$ Both primary and secondary EU law have primacy over national laws of the

11 Slovak Republic v Achmea BV C-284/16), ECLI: EU: C:2018:158, also Rosas, op. cit. p 11., Nagy (2018) 981-1016.

12 Opinion 1/17 of the Court, see: Riffle (2019) 503-21.

13 See case law in Rosas (2018) 6. 
Member States and the higher rank of EU law is reinforced by its direct effect, in fact by the synergic effect of the combination of both principles.

Although the Court's claim elaborated in Costa and in subsequent case law was for an unreserved, absolute EU law primacy, the concept of constitutional identity, as developed by the constitutional Courts of member states, clearly challenged the absolute nature of this ranking. EU law still ranks above national law but there is an area of exceptions, which is not precisely defined and is subject to legal and political arguments and to the developments of Member States' constitutional law. Again, the 'unreserved, absolute' ranking is becoming less unambiguous, and the vertical hierarchy is modified by heterarchic features. The commonalities between the concepts of the autonomy of EU law and the constitutional identity of member states all ultimately originate from the fundamental question of the legal status and nature of the European Union. There is no clear answer to the question of the legal nature, i.e. whether the EU is an international organisation (with distinctive features) or it is an embryonic federation, a quasi federal state. The specificity of the EU can, of course, be described by compromises, like it is a sui generis institution or by linguistic innovations (like Staatenbund or fédération d'États-nations), but the finding of any intermediate terminology does not give an answer to the substantial dilemma of the legal nature of the entity and the precise status of the rules created by it. It is a question that goes beyond the scope of action of legal scholarship, and essentially depends on the general developments of the European integration process.

This brings back the questions relating to general developments. How can a balance be established between the economic and the political dimension (pillar) of the process, how can the economic and trade power be transformed in a geopolitical clout? How can the Union combine economic and political power and use the synergy of the trade and the flag in its external relations and as a result, how can the Union become, despite all the challenges and threats, a far more important global actor? However, establishing a balance between the economic and political dimension of the integration is a minor or secondary issue as against the upgrading of the third relatively neglected cultural dimension. This is what a strong European identity could and should be built upon.

The first thing to be recognized is that European identity is a collective identity because it is an identity shared by millions of people belonging to the same community. Such communities can be called tribes, and term the recognition of collective identities as tribalism. The specific wording is not important unlike the meaning and the substance. Humans have always formed and belonged to communities, and developed a cognitive and emotional attachment to those groups. ${ }^{14}$ The sense of affiliation can also be multiple, stronger or weaker to the various smaller or larger groups. For thousands of years these groups were called tribes. Some of them are still called tribes and do not carry a negative overtone.

The strongest and most enduring attachment modern history developed is national affiliation, expressed by national identity. This serves as a basis for the concept of the nation in a cultural sense, a cultural nation. Names may vary, it can be called tribalism, but the substance remains the same as well as the facts upon which successful policies can be built. 
Group attachments are not exclusive, nothing prevents the existence of additional group attachments supplementing the primary national attachment. Additional or secondary attachment, a collective sense of being European, has also been formed and shaped by history, and is also subject to further future development.

Once the existence and membership of a 'European tribe' has been acknowledged, two basic tasks are to be performed. The first is to achieve some degree of consensus upon the core elements of the European identity, and then to strengthen and deepen this identity whilst respecting the reality, in particular, the primacy of national identity.

The first task is the easier one. The core elements are well known, even if not always fully respected. The elements of European identity have to be identified where there is disagreement, unfolding and analysing the reasons of the differences rooted in the diversity of historical experiences. Repeating the slogan 'unity in diversity' will not be sufficient without understanding, accepting and respecting the legitimacy of those differences. At the end of this exercise, it might turn out that there is more agreement on many more elements than it is often believed and suggested, and there are disparate visions as for the order of importance of the same elements, indeed, values.

There are various approaches to questions such as how those elements of European identity have to be put in effect and how they are to be transformed into political decisions forming the European integration or more generally, European life. Again, emphasis may be placed upon different aspects, but the ultimate outcome could be much more encouraging than the picture drawn from the ideological and political divisions.

There is a strong agreement that law has not only been an indispensable device of establishing, building, developing and saving European integration, but it is a core element of European identity. The two roles of law are intertwined, but each of the two needs to be respected. Law as a technique must be applied with reasonable self-restraint, avoiding all or any temptation of using it selectively for political purposes. ${ }^{15}$ The basic conceptual and structural order of legal rules, be it legislation or case law, always has to be respected, in particular, when law is used for basic economic, political and cultural constructions such as the European integration. European law as a core element of European identity has to be embedded in the universal legal order. Rule of law is universal, it has to be respected on European as well as on universal level. The growing fragmentation, pluralisation and regionalisation of international law and the changing, more diffuse geometry of legal rules reflect the current general tendencies of the global economy, the world trading system and geopolitics alike. However, law should not give up its basic mission, which is to bring order to the growing disorder or at least to alleviate the consequences following from the phenomenon some call entropy. Law always has to be on the side of harmony constituting the source of external energy, whereby the increase of disorder can be stopped or at least slowed down. The strict hierarchy of legal order may become heterarchic, but it has to remain orderly and competences must be respected. This does not exclude the room for reasonable flexibility and mutual understanding, quite to the contrary, it presupposes a constructive dialogue, cooperation and concertation between all levels of rulemaking, not only legislation and regulation, but also between the judiciaries. This is the way law could make a substantive and not only technical contribution to the future of European integration.

15 Ziegler (2015) 16. 
The success of this future primarily depends on the question of how the present lopsided relationships between three dimensions of the process, the economic, the political and the cultural/spiritual can be rebalanced, how the present disequilibrium between trade policy and CFSP/CSDP can be reduced by strengthening the Union's external action and global role, and, first and foremost, how the cultural/spiritual dimension, the soul, indeed, the collective identity of Europe can be uplifted at least to the level of the former two dimensions.

The task is to continue to trade, to raise the flag and to call back the missionary.

\section{LITERATURE}

Blutman, L., A nemzetközi jog érvényesülése a magyar jogban: fogalmi keretek (Hungarian Academy of Sciences thesis 2015).

Chua, A., 'Tribal World, Group Identity is All' (2018) 4. Foreign Affairs 25-33.

Nagy, Cs. I., 'Intra-EU Bilateral Investment Treaties and EU Law after Achmea: "Know Well What Leads You Forward and What Holds You Back"' (2018) 4 German Law Journal, Vol. 19, No. 4, pp. 981-1016.

Reho, F. O., For a New Europeanism (Martens Centre 2017).

Riffle, C., 'The CETA Opinion of the European Court of Justice and its Implications - Not that Selfish After All' (2019) 3 Journal of International Economic Law 503-21.

Rosas, A., The European Court of Justice and Public International Law (2018) Meeting of the Council of Europe Committee of Legal Advisers on Public International Law, Strasbourg, 23 March 2018 $1-11$.

Ziegler, K., 'International Law and EU Law: Between Asymmetric Constitutionalisation and Fragmentation' in Orakhelashvili, A. (ed.) Research Handbook on the Theory and History of International Law (Edward Elgar 2011) 300-03.

Ziegler, K., 'The Relationship between EU Law and International Law' (2015) 4 University of Leicester School Research Paper.

Ziegler, K., 'Autonomy: From Myth to Reality - Or Hubris on a Tightrope? EU Law, Human Rights and International Law' in Douglas-Scott, S., (ed) Research Handbook on EU Law and Human Rights (Edward Elgar 2016) 267-308.

\section{OPEN ACCESS}

This is an open-access article distributed under the terms of the Creative Commons Attribution 4.0 International License (https://creativecommons.org/licenses/by/4.0), which permits unrestricted use, distribution, and reproduction in any medium, provided the original author and source are credited, a link to the CC License is provided, and changes - if any - are indicated. (SID_1). 